\title{
Penerapan Analisis SWOT terhadap Strategi Pemasaran Pie Susu Zingiberaceae saat Pandemi Covid-19
}

\author{
Ziyana Walidah ${ }^{1 *}$, Eva Aulina Wardani ${ }^{1}$, Ayu Risky Wulandari ${ }^{1}$, \\ Faradilla Putri Mahendra ${ }^{1}$, Ria Setya Ningtyas ${ }^{2}$, Deltaningtyas Tri Cahyaningrum ${ }^{1}$ \\ ${ }^{1}$ Department of Agribusiness Management, Politeknik Negeri Jember \\ ${ }^{2}$ Department of Health, Politeknik Negeri Jember \\ *ziy.walidah@gmail.com
}

Submitted: 17 Mar 2021

Accepted: 21 Jun 2021

Published: 28 Jun 2021

\begin{abstract}
ABSTRAK
Tujuan penelitan ini untuk menganalisis penerapan SWOT terhadap strategi pemasaran pada Pie Susu Zingiberaceae dengan melihat faktor-faktor yang berpengaruh pada pemasaran produk. Sebagaimana yang kita tahu bersama bahwa Pie menjadi salah satu jenis pastry yang popular dibanyak negara salah satunya di Indonesia. Salah satu pengembangan pie di Indonesia adalah pie susu. Pie susu memiliki banyak varian rasa, namun belum banyak pie susu yang menggunakan tanaman herbal terutama tanaman herbal dari suku zingiberaceae. Penggabungan antara pie susu dengan beberapa tanaman herbal dari suku zingiberaceae menjadi variasi baru yang sangat bermanfaat dan memiliki peluang pasar yang besar di kalangan masyarakat Indonesia. Persaingan bisnis yang kompetitif dengan adanya pandemi Covid-19 menuntut para pelaku usaha untuk melakukan strategi promosi. Dengan analisis SWOT didapatkan bahwa posisi produk berada pada Opportunity-Strength yang artinya strategi yang diambil adalah penjualan dilakukan secara online dengan memberikan deskripsi tentang pie susu Zingiberaceae.
\end{abstract}

Kata kunci: Pie Susu, Zingiberaceae, analiis SWOT, Pemasaran, Covid-19

\section{ABSTRACT}

The purpose of this study to analyze the application of SWOT analysis to the marketing strategy of Pie Susu Zingiberaceae by looking at the factors that influence product marketing. As we all know, pie is one of the most popular types of pastry in various countries, one of which is Indonesia. One of the developments of pie in Indonesia is milk pie. Milk pie has many flavors, but not many milk pie uses herbal plants, especially herbs from the zingiberaceae tribe. The combination of milk pie with several herbal plants from the zingiberaceae tribe becomes a new variety that is very useful and has a large market opportunity among the people of Indonesia. The current competitive business competition and especially with the Covid-19 pandemic requires business actors to implement accurate strategies in carrying out promotional strategies in an effort to attract consumer interest. In overcoming this, an analysis is carried out to determine the factors that influence the marketing strategy using SWOT analysis. So that it is known which factors need to be improved and maintained to strengthen the marketing strategy for Pie Susu Zingiberaceae products.

Keyword: Milk Pie, Zingiberaceae, SWOT analysis, Marketing, Covid-19

\section{Pendahuluan}

Pie menjadi salah satu jenis pastry yang popular dibanyak negara salah satunya di Indonesia. Salah satu pengembangan pie di Indonesia adalah pie susu. Pie susu memiliki banyak varian rasa, namun belum banyak pie susu yang menggunakan tanaman herbal terutama tanaman herbal dari suku zingiberaceae. Penggabungan antara pie susu dengan beberapa tanaman herbal dari suku zingiberaceae menjadi variasi baru yang sangat bermanfaat dan memiliki peluang pasar yang besar di kalangan masyarakat Indonesia. Zingiberaceae secara umum dikenal oleh masyarakat Indonesia sebagai tumbuhan jahejahean. Beberapa diantaranya adalah jahe (Zingiberofficinale), kunyit (Curcuma 
dosmetica) dan temulawak (Curcuma xanthorrhiza). Jahe (Zingiberofficinale Roscoe) merupakan tanaman dari genus Zingiber Mill (GBIF, 2019).

Semenjak awal tahun 2020, dunia dilanda pandemi Covid-19 yang mengakibatkan jatuhnya perokonomian berbagai negara di dunia. Indonesia menjadi salah satu negara yang terdanpak akan pandemi Covid-19. Persaingan bisnis yang kompetitif saat ini dan terlebih dengan adanya pandemi Covid-19 menuntut para pelaku usaha untuk menerapkan strategi yang jitu dalam melakukan strategi promosi dalam upaya memikat minat konsumen. Hal ini dilakukan agar produk yang ditawarkan dapat merayu calon konsumen sehingga termotivasi untuk melakukan pembelian produk.

Penjualan produk suatu usaha dibutuhkan pemasaran yang berorientasi masa depan. Artinya, bahwa pelaku usaha mampu memperluas jangkauan produk, perubahan strategi, dapat mengantisipasi tantangan keadaan yang akan dihadapi, meningkatkan seluruh kualitas pelayanan dan paling utama yaitu efektivitas pemasaran produk untuk dapat meningkatkan penjualan produk usaha tersebut. Untuk itu, penulis melakukan observasi studi kasus mengenai analisis SWOT terhadap strategi pemasaran produk pie susu zingiberaceae di tengah pandemi Covid-19.

\section{Metode Penelitian}

Penelitian ini menggunakan metode penelitian kualitatif-deskriptif dengan pendekatan studi kasus tentang strategi pemasaran di tengah pandemi Covid-19 pada usaha produk pie susu zingiberaceae. Penelitian kualitatif dapat mengungkapkan peristiwaperistiwa nyata yang terjadi di lapangan dan juga menekankan sifat alamiah dari peristiwa yang terjadi.

Metode pengumpulan dalam penelitian ini menggunakan metode observasi. Adapun metode pengumpulan data sebagai berikut :

Observasi. Pada tahap ini, penulis melaksanakan kunjungan dan melakukan pengamatan bebarapa produk UMKM sejenis yang ditawarkan pada tempat penjualan seperti pusat oleh-oleh, swalayan milik kampus, dan depot jamu. Selain itu, penulis melakukan pengamatan beberapa UMKM sejenis yang ditawarkan melalui aplikasi Shopee dan Instagram dengan jenis-jenis strategi yang ditawarkan.

\section{Hasil dan Pembahasan}

Berdasarkan hasil penelitian didapatkan bahwa produk pie susu zingiberaceae beroperasi selama 1 bulan pada bulan Juni sebesar Rp 2.100.000,00, dengan rata-rata perharinya sebesar Rp 70.000. Secara detail, dapat dilihat diagram 1.1 di bawah ini.

\section{Diagram 1.1 Omset bulan Juni 2021}

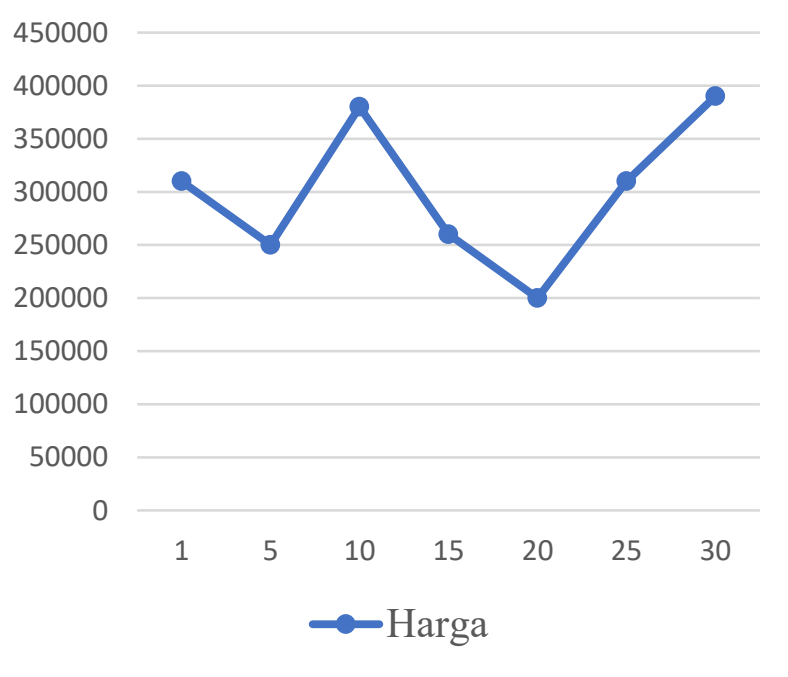

Analisis SWOT adalah alat yang digunakan oleh suatu perusahaan untuk mengidentifikasi atau mengevaluasi faktor-faktor internal maupun eksternal perusahaan.

\subsection{Analisis Lingkungan Internal}

\subsubsection{Kekuatan (strength)}

a. Proses produksi pie susu zingiberaceae diproduksi dengan bahan berkualitas yakni dengan bahan yang bermerek, bahan herbal yang masih segar, dan tanpa pengawet. Sehingga produk pie susu yang dihasilkan lebih berkualitas dari segi rasa dan teksturnya.

b. Produk pie susu zingiberaceae memiliki rasa yang enak dan bernutrisi tinggi. Hal ini dibuktikan dengan beberapa testimoni dan review dari konsumen yang telah mencoba produk secara langsung. 
c. Produk pie susu zingiberaceae dapat digunakan sebagai alternatif penunda lapar. Sebagai camilan yang berbahan dasar dari tepung terigu yang mengandung karbohidrat dan telur sebagai protein, maka hal tersebut membuktikan bahwa pie susu zingiberaceae dapat digunakan sebagai camilan alternatif penunda lapar.

d. Harga produk pie susu zingiberaceae yang terjangkau dikalangan konsumen. Pie susu zingiberaceae dijual dengan harga $\mathrm{Rp}$ $1.500 / \mathrm{pcs}$.

\subsubsection{Kelemahan (weakness)}

a. Produk tidak tahan lama. Produk pie susu zingiberaceae hanya dapat bertahan selama 2 minggu karena tidak menggunakan bahan pengawet.

b. Diproduksi secara terbatas. Pie susu zingiberaceae dipasarkan dengan sistem preorder, sehingga produk hanya diproduksi sesuai dengan jumlah pesanan yang masuk saat pre-order dibuka.

c. Rasa produk yang belum familiar di masyarakat. Produk pie susu zingiberaceae merupakan produk pie susu dengan cita rasa baru dengan yaitu jamu-jamuan atau tanaman herbal suku zingiberaceae.

d. Sumber daya manusia masih kurang. Proses produksi pie susu zingiberaceae hanya dikerjakan oleh 5 orang karyawan.

e. Pemasaran produk tergolong lokal. Pemasaran produk masih sekitar daerah Jember dan sekitarnya.

\subsection{Analisis Lingkungan Eksternal}

\subsubsection{Peluang (opportunity)}

a. Adanya sifat konsumtif di masyarakat akan produk baru, unik, dan kekinian. Baru-baru ini, kantar mempublikasikan hasil penelitiannya di Indonesia pada Maret 2020 yang menunjukkan bahwa 90 persen responden mulai mencoba mengonsumsi menu makanan sehat, 61 persen menguji resep-resep makanan baru, dan 41 persennya mengonsumsi snack harian lebih banyak dari biasanya. b. Produk masih jarang di pasaran. Selain itu, produk yang masih jarang di pasaran menunjukkan jumlah pesaing masih sedikit.

c. Mengikuti kemajuan teknologi untuk menciptakan pemasaran produk yang maksimal. Dengan adanya pandemi COVID19 ini, pemasaran yang kita lakukan melalui online guna untuk memperkecil kemungkinan terpaparnya virus corona. Untuk pemasaran offline dilakukan hanya di sekitar Jember.

d. Melihat tingkat daya beli dari masyarakat. Dengan adanya sifat masyarakat yang memiliki rasa ingin tahu yang besar, produk pie susu zingiberaceae dapat menarik minat masyarakat sebagai produk inovasi pie susu rasa herbal dengan harga yang lebih terjangkau dari pie susu biasanya.

\subsubsection{Ancaman (threat)}

a. Persaingan dengan makanan ringan yang memiliki masa konsumsi lebih lama. Produk pie susu zingiberaceae tidak menggunakan bahan pengaweet sehingga produk hanya bertahan hingga 2 minggu. Sedangkan produk makanan ringan yang telah beredar di masyarakat dapat bertahan lebih dari 2 minggu.

b. Persaingan dengan produk sejenis yang memiliki varian rasa lebih familiar. Pie susu zingiberaceae merupakan pie susu inovasi baru sehingga dapat menimbulkan keraguan konsumen untuk mencoba.

c. Banyak peniru produk. Karena produk ini merupakan produk baru, maka peluang untuk ditiru menjadi besar.

d. Ketersediaan harga bahan baku yang dapat naik sewaktu-waktu karena harga bahan pokok yang digunakan cenderung naik seperti telur dan gula.

\subsection{Matriks IFAS (Internal Factor Analysis Summary)}

Setelah faktor-fator strategis internal usaha pie susu zingiberaceae diidentifikasi, suatu tabel IFAS (Internal Factor Analysis Summery) disusun untuk merumuskan faktor-faktor strategis internal tersebut dalam kerangka strength dan weakness pie susu zingberaceae. Tahapannya adalah: 
a. Tentukann faktor-faktor yang menjadi kekuatan serta kelemahan usaha pie susu zingiberaceae dalam kolom.

b. Beri bobot masing masing faktor tersebut dengan skala mulai dari 1,0 (paling penting) sampai 0,0 (tidak penting), berdasarkan pengaruh faktor-faktor tersebuut terhadap posisi strategis usaha pie susu zingiberaceae. (semua bobot tersebut jumlahnya tidak boleh melebihi skot total 1,00).

c. Berikan rating 1 sampai 4 bagi masing-masing faktor untuk menunjukkan apakah faktorfaktor tersebut memiliki kelemahan yang besar (rating $=1$ ), kelemahan yang kecil (rating $=3$ ), dan kekuatan yang kecil (rating = 4). Jadi, sebenarnya, rating mengacu pada industri dimana usaha pie susu zingiberaceae berada.

d. Kalikan masing-masing bobot dengan ratingnya untuk mendapatkan skor.

e. Jumlahkan total skor masing-masing variabel.

Berapapun banyaknya faktor yang dimasukkan dalam matrik IFAS, total rata-rata tertimbang berkisar antara yang rendah 1,0 dan tertinggi 4,0 dengan rata- rata 2,5. Jika total ratarata dibawah 2,5 menandakan bahwa secara internal perusahaan lemah, sedangkan total nilai diatas 2,5 mengindikasikan posisi internal yang kuat.

Table 1. Matriks IFAS (Internal Factor Analysis Summary)

\begin{tabular}{|c|c|c|c|c|}
\hline No & Faktor Internal & Bobot & Rating & Skor \\
\hline \multicolumn{5}{|c|}{ Kekuatan (Strength) } \\
\hline 1 & $\begin{array}{l}\text { Proses produksi pie susu zingberaceae masih secara manual dengan bahan } \\
\text { berkualitas, jadi produk pie susu yang dihasilkan lebih berkualitas dari segi rasa dan } \\
\text { teksturnya. }\end{array}$ & 0,15 & 4 & 0,60 \\
\hline 2 & Produk pie susu zingiberaceae memiliki rasa yang enak dan bernutrisi tinggi. & 0,17 & 3 & 0,51 \\
\hline 3 & Produk pie susu zingiberaceae dapat digunakan sebagai alternative penunda lapar. & 0,13 & 3 & 0,39 \\
\hline 4 & Harga produk pie susu zingiberaceae yang terjangkau dikalangan konsumen. & 0,15 & 4 & 0,60 \\
\hline \multicolumn{2}{|c|}{ Subtotal } & 0,6 & 14 & 2,1 \\
\hline \multicolumn{5}{|c|}{ Kelemahan (Weakness) } \\
\hline 1 & Produk tidak tahan lama. & 0,09 & 2 & 0,18 \\
\hline 2 & Diproduksi secara terbatas. & 0,07 & 3 & 0,21 \\
\hline 3 & Rasa produk yang belum familiar yang di masyarakat. & 0,09 & 2 & 0,18 \\
\hline 4 & Sumber daya masih kurang. & 0,08 & 2 & 0,16 \\
\hline 5 & Pemasaran produk tergolong lokal. & 0,07 & 2 & 0,14 \\
\hline \multicolumn{2}{|c|}{ Subtotal } & 0,4 & 11 & $\mathbf{0 , 8 7}$ \\
\hline \multicolumn{2}{|c|}{ Total } & 1 & 25 & 2,97 \\
\hline
\end{tabular}

Dari hasil analisis pada tabel 1.1 IFAS, faktor kekuatan dan kelemahan memiliki total skor 2,97. Karena total skor berjumlah diatas 2,5 berarti ini mengindikasikan posisi internal produk usaha pie susu zingiberaceae begitu kuat.

\subsection{Matriks EFAS (Eksternal Factor Analysis Summary)}

Ada lima tahap penyusunan matriks faktor strategi eksternal yaitu:

a. Tentukan faktor-faktor yang menjadi peluang dan ancaman.

b. Beri bobot masing-masing faktor mulai dari 1,0 (sangat penting) sampai dengan 0,0 (tidak penting). Faktor-faktor tersebut kemungkinan dapat memberikan dampak terhadap faktor 
strategis. Jumlah seluruh bobot harus sama dengan 1,0 .

c. Menghitung rating untuk masing-masing faktor dengan memberikan skala mulai 1 sampai 4 , dimana 4 (respon sangat bagus), 3 (respon di atas rata- rata), 2 (respon rata-rata), 1 (respon di bawah rata-rata). Rating ini berdasarkan pada efektivitas strategi usaha pie susu zingiberaceae, dengan demikian nilainya berdasarkan pada kondisi usaha.

d. Kalikan masing-masing, bobot dengan ratingnya untuk mendapatkan skor.

e. Jumlahkan semua skor untuk mendapatkan total skor usaha pie susu zingiberaceae. Nilai total ini menunjukkan bagaimana usaha pie susu zingiberaceae bereaksi terhadap faktorfaktor strategi eksternalnya.

Sudah tentu bahwa dalam EFAS matrix, kemungkinan nilai tertinggi total skor adalah 4,0 dan terendah adalah 1,0. Total skor 4,0 mengindikasikan bahwa usaha pie susu zingiberaceae merespon peluang yang ada dengan cara yang luar biasa dan menghindari ancaman-ancaman di pasar industrinya. Total skor 1,0 menunjukkan strategi-strategi usaha pie susu zingiberaceae tidak memanfaatkan peluang-peluang atau tidak menghindari ancaman-ancaman eksternal.

Table 2. Matriks EFAS (External Factor Analysis Summary)

\begin{tabular}{|c|c|c|c|c|}
\hline No & Faktor Eksternal & Bobot & Rating & Skor \\
\hline \multicolumn{5}{|c|}{ Kesempatan (Opportunity) } \\
\hline 1 & Adanya sifat konsumtif di masyarakat akan produk baru, unik, dan kekinian. & 0,18 & 4 & 0,72 \\
\hline 2 & Produk masih jarang di pasaran. & 0,17 & 4 & 0,68 \\
\hline 3 & $\begin{array}{l}\text { Mengikuti kemajuan teknologi untuk menciptakan pemasaran produk yang } \\
\text { maksimal. }\end{array}$ & 0,19 & 3 & 0,57 \\
\hline 4 & Melihat tingkat daya beli dari masyarakat. & 0,16 & 3 & 0,48 \\
\hline \multicolumn{2}{|c|}{ Subtotal } & $\mathbf{0 , 7}$ & 14 & 2,45 \\
\hline \multicolumn{5}{|c|}{ Ancaman (Threats) } \\
\hline 1 & Persaingan dengan makanan ringan yang memiliki masa konsumsi lebih lama. & 0,05 & 2 & 0,10 \\
\hline 2 & Persaingan dengan produk sejenis yang memiliki varian rasa lebih familiar. & 0,07 & 3 & 0,21 \\
\hline 3 & Banyak peniru produk. & 0,04 & 1 & 0,04 \\
\hline 4 & Sumber daya masih kurang. & 0,08 & 3 & 0,24 \\
\hline 5 & Ketersediaan harga bahan baku yang dapat naik sewaktu-waktu. & 0,06 & 1 & 0,06 \\
\hline \multicolumn{2}{|r|}{ Subtotal } & $\mathbf{0 , 3}$ & 10 & $\mathbf{0 , 6 5}$ \\
\hline \multicolumn{2}{|c|}{ Total } & 1 & 24 & 3,1 \\
\hline
\end{tabular}

Dari hasil analisis pada tabel 4.4 EFAS, faktor peluang dan ancaman memiliki total skor 3,1. Karena total skor mendekati 4,0, berarti ini mengindikasikan bahwa usaha pie susu zingiberaceae merespon peluang yang ada dengan cara yang luar biasa dan menghindari ancaman-ancaman di pasar industrinya.

Selanjutnya, nilai total skor masing-masing faktor dapat dirinci, strength 2,1, weakness 0,87 , opportunity 2,45 dan threat 0,65 , maka diketahu selisih total skor faktor strength dan weakness adalah $(+) 1,23$, sedangkan selisih total skor faktor opportunity dan threats adalah $(+)$ 1,8. Dibawah ini merupakan gambar diagram cartesius analisis SWOT usaha pie susu zingiberaceae: 


\section{Opportunity}

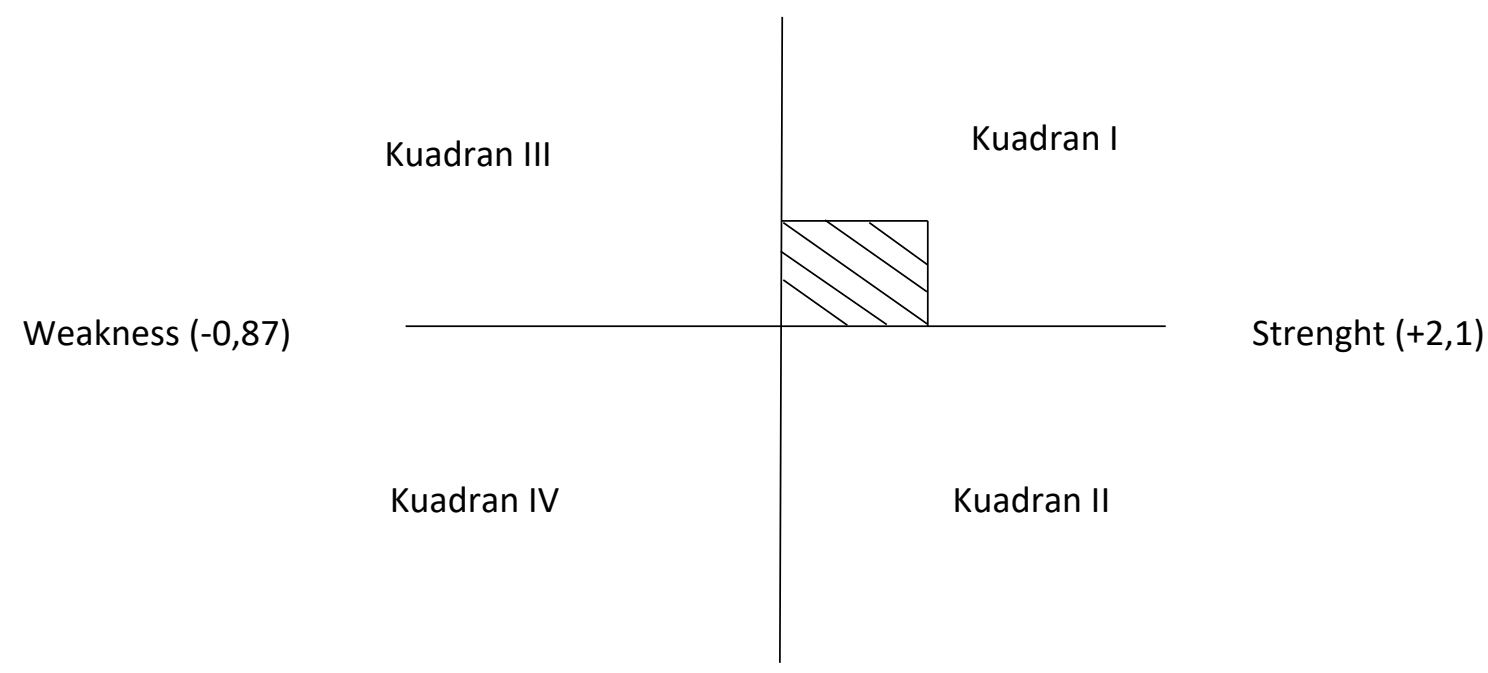

Threat $(-0,65)$

\subsection{Matriks SWOT}

Matriks SWOT merupakan alat yang dipakai untuk mengukur faktor-faktor strategi perusahaan. Matriks ini dapat menggambarkan secara jelas bagaimana peluang dan ancaman eksternal yang dimiliki. Matriks ini dapat menghasilkan empat sel kemungkinan alternatif strategi yang dapat dilihat pada tabel dibawah ini:

Table 3. Matriks SWOT

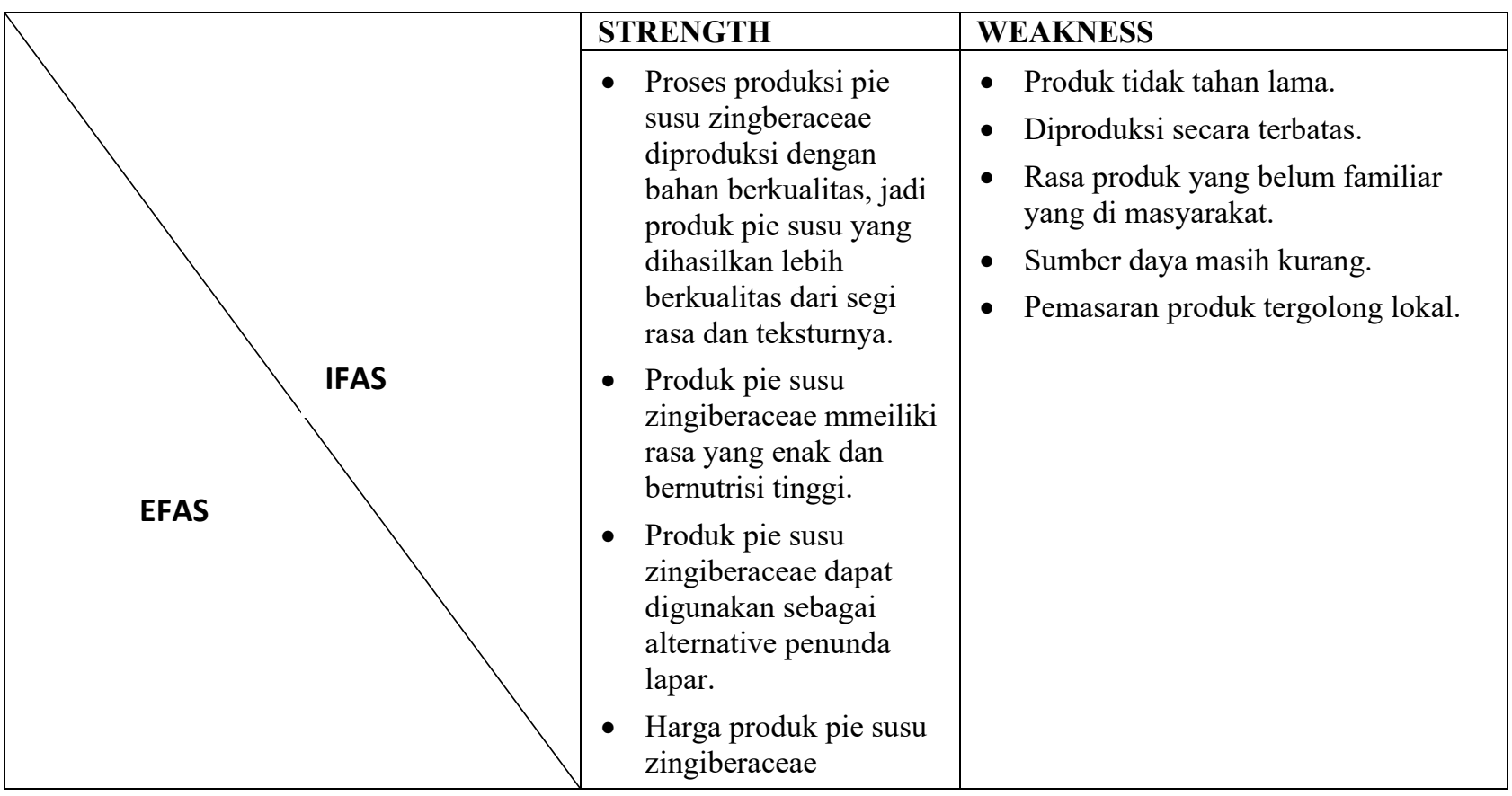




\begin{tabular}{|c|c|c|}
\hline OPPORTUNITY & STRATEGI SO & STRATEGI WO \\
\hline $\begin{array}{l}\text { - Adanya sifat konsumtif di masyarakat } \\
\text { akan produk baru, unik, dan kekinian. } \\
\text { - } \\
\text { - } \\
\text { - Mengikuti kemajuan teknologi untuk } \\
\text { menciptakan pemasaran produk yang } \\
\text { maksimal. } \\
\text { - Melihat tingkat daya beli dari } \\
\text { masyarakat. }\end{array}$ & $\begin{array}{l}\text { - Meningkatkan strategi } \\
\text { pemasaran melalui } \\
\text { sosial media dengan } \\
\text { mengikuti kemajuan } \\
\text { teknologi } \\
\text { - Mengutamakan } \\
\text { kualitas produk dengan } \\
\text { melihat daya beli serta } \\
\text { permintaan konsumen } \\
\text { Kualitas tanpa bahan } \\
\text { pengawet serta harga } \\
\text { yang terjangkau } \\
\text { menjadi faktor utama } \\
\text { dalam } \\
\text { mempertahankan } \\
\text { konsumen yang } \\
\text { bersifat konsumtif }\end{array}$ & $\begin{array}{l}\text { Meningkatkan kualitas sumberdaya } \\
\text { agar dapat memenuhi permintaan } \\
\text { konsumen yang tinggi } \\
\text { - Memberikan review atau testimoni } \\
\text { dengan mempostingnya di sosial } \\
\text { media sehingga konsumen baru } \\
\text { percaya dan tertarik untuk } \\
\text { melakukan pembelian } \\
\text { Memperluas pasar melalui kerjasama } \\
\text { dengan mitra bisnis seperti toko } \\
\text { oleh-oleh dan lain sebagainya }\end{array}$ \\
\hline THREAT & STRATEGI ST & STRATEGI WT \\
\hline $\begin{array}{l}\text { - Persaingan dengan makanan ringan } \\
\text { yang memiliki masa konsumsi lebih } \\
\text { lama. } \\
\text { - Persaingan dengan produk sejenis yang } \\
\text { memiliki varian rasa lebih familiar. } \\
\text { - Banyak peniru produk. } \\
\text { - Ketersediaan harga bahan baku yang } \\
\text { dapat naik sewaktu-waktu. }\end{array}$ & 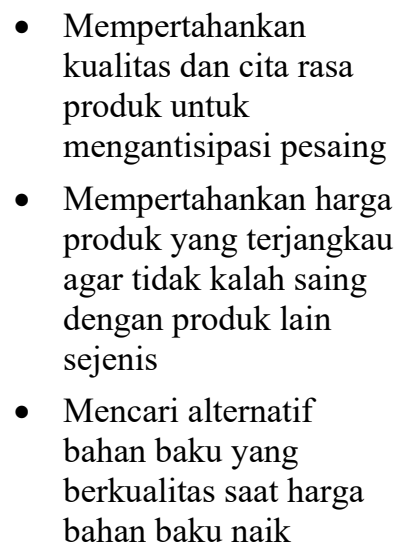 & $\begin{array}{l}\text { Melakukan strategi pemasaran yang } \\
\text { dapat menarik konsumen dengan } \\
\text { memanfaatkan cita rasa produk yang } \\
\text { belum ada di pasaran } \\
\text { - Mematenkan nama produk agar } \\
\text { tidak ditiru oleh pelaku usaha lain } \\
\text { - Menyusun strategi pemasaran yang } \\
\text { lebih mengena ke masyarakat } \\
\text { terutama di masa covid-19 }\end{array}$ \\
\hline
\end{tabular}

\section{Kesimpulan}

Dari hasil analisis SWOT pada strategi pemasaran usaha Pie Susu Zingiberaceae dapat disimpulkan bahwa strategi tersebut dapat mendorong dan meningkatkan penjualan Pie Susu Zingiberaceae ditengah pandemi Covid19. Promosi yang dilakukan melalui media online (digital) mendukung strategi pemasaran sehingga produk yang ditawarkan dapat dikenal dan tercipta brand awareness di benak masyarakat.

Omset penjualan secara cepat dapat meningkat dengan menerapkan manajemen pemasaran yang lebih baik dengan tetap menaati etika bisnis yang ada. Strategi pemasaran tersebut menjadikan usaha Pie Susu Zingiberaceae berangsur naik dan menjadi produk baru yang terkenal dengan kualitas produk yang baik terutama di tengah pandemi covid-19 yang terjadi di Indonesia saat ini. Hal ini menunjukkan bahwa kebijakan pemasaran yang diterapkan sudah tepat dan efektif dengan nilai presentase omset yang terus meningkat.

\section{Daftar Pustaka}

[1] Andries, F. R. "Perumusan Strategi Pemasaran Berdasarkan Analisis SWOT Studi Kasus Pada PT Waringin Puspanusa Lestari Jakarta". Skripsi, Yogyakarta: Fakultas Ekonomi, Sanata Dharma. 2007.

[2] GBIF, 2019. "Zingiber officinale Roscoe". [Online] Available at: https://www.gbif.org/species/2757280. Accessed 22 May 2020].

[3] Heriawan, F., Susanto, A. B., \& Haryanti, D. "Strategi Pemasaran, Penjualan dan Produksi Olahan Rumput Laut Berbasis IT saat Pandemi Covid-19 di Padepokan Suket Segoro Semarang". Journal of Marine Research, 10(1), 138-146. 2021. 
[4] Kuspriyono, T. "Strategi Promosi Swalayan Depok (Swadep) Di Masa Pandemi Covid 19". Jurnal Akrab Juara, 6(2), 45-55. 2021.

[5] Rangkuti, F. "Analisis Swot Teknik Membedah Kasus Bisnis". Jun. 2006.

[6] Syaiful, F. F., \& Elihami, E. "Penerapan Analisis SWOT Terhadap Strategi Pemasaran Usaha Minuman Kamsia Boba Milik Abdullah Di Tengah Pandemi Covid-19 Di Kabupaten Bangkalan”. Jurnal Edukasi Nonformal, 1(2), 343-359. 2020.

[7] Saharuddin, A., Wijaya, T., Elihami, E., \& Ibrahim, I. "Literation Of Education And Innovation Business Engineering Technology". Jurnal Edukasi Nonformal, 1(1), 48-55.2020.

[8] Sandy, A. T., Kadarsah, A., Nafiah, A., Kuswoyo, A., Syarifuddin, A., Sutadji, E., ... \& Setiawan, S. "Di Balik Wabah Covid-19 Sumbangan Pemikiran Dan Perspektif Akademis". 2020.

[9] Wartoyo, P. "Enam Alat Analisis Manajemen”. 2011.

[10] Yusuf, S. M., \& Said, M. "Konsep dan Strategi Pemasaran”. 2019. 